\title{
The potential of reservoirs for both flood control and irrigation in the Sebou River (Morocco)
}

\author{
Ikram BENCHBANI $^{1}$ a, Karima SEBARI ${ }^{1}$, Mahmoud ZEMZAMI $^{2}$ and Younes LAABDI ${ }^{2}$ \\ ${ }^{1}$ Hassan II Institute of Agronomy and Veterinary Medecine, Department of rural engineering, Rabat, Morocco \\ ${ }^{2}$ Ministry of Equipment, Transport, Logistics and Water, General Directorate of Hydraulics, Studies and water planning division, Rabat, \\ Morocco
}

\begin{abstract}
Protecting the population and property against floods is one of the Moroccan National Water Plan priorities. Indeed, based on the National Flood Protection Plan established in 2002 and updated in 2017, 1,032 vulnerable sites were identified with different risk levels: low, medium and high. In the North West part of Morocco, the Gharb plain has experienced many flood events, the most devastating is the one occurred on 1970 and has caused many causalities. The floods affect negatively the irrigation network of the Gharb plain and hamper the optimal water resources management in the Sebou basin. Al Wahda Dam was built in 1996, with a total capacity of 3.7 billion of cubic meter, and an objective of ensuring both the irrigation and the protection of the Gharb plain against flooding. Since that, the dam contributed effectively on the protection of the downstream region. However, with increasing extreme events frequency the region has experienced significant floods (2009 and 2010). The scope of this paper is to examine the opportunity of constructing large dams upstream Al Wahda dam to ensure an effective flood risk management by increasing the capacity of the dams to handle extreme floods. The hydraulic simulations were carried out with the decision support system for integrated water resource planning and management RIBASIM. The results showed that the increase in the storage capacity upstream of Al Wahda, will not be sufficient on its own for the protection of the Gharb plain against flooding, but we must think of other actions to be implemented downstream of the Sebou river.
\end{abstract}

\section{Introduction}

Floods are the most frequent, most damaging and deadliest natural disasters worldwide [1]. In the last 50 years, floods are the source of nearly half of natural disaster and cause nearly the third of global economic losses [2]. Floods are weather-related hazards, their patterns are likely to be significantly affected by climate change, and the Mediterranean area is exposed to it [3-5].

In common with all Mediterranean countries, Morocco recorded, between 1951 and 2015, a least 35 flood episodes [6]. In the past, floods were destined to irrigation by water spreading in arid area according to ancestral practices. However, with the population growth and infrastructure development, these floods generate enormous damage to human lives and infrastructures.

Based on the National Flood Protection Plan established in 2002 and updated in 2017 [7], 1,032 vulnerable sites were identified with different risk levels: low, medium and high. Figure 1 shows the historical floods events in Morocco.

Morocco has planned and implemented dam policies for flood protection and water supply since 1967 and constructed large-scale dams such as Al Wahda dam, Hassan Addakhil dam, Oued El Makhazine dam [8-9].
Despite these efforts, violent floods have occurred continuously during past decades due to the rapid population growth and the development in various domains such as economy, urbanization, agriculture, industry and tourism.

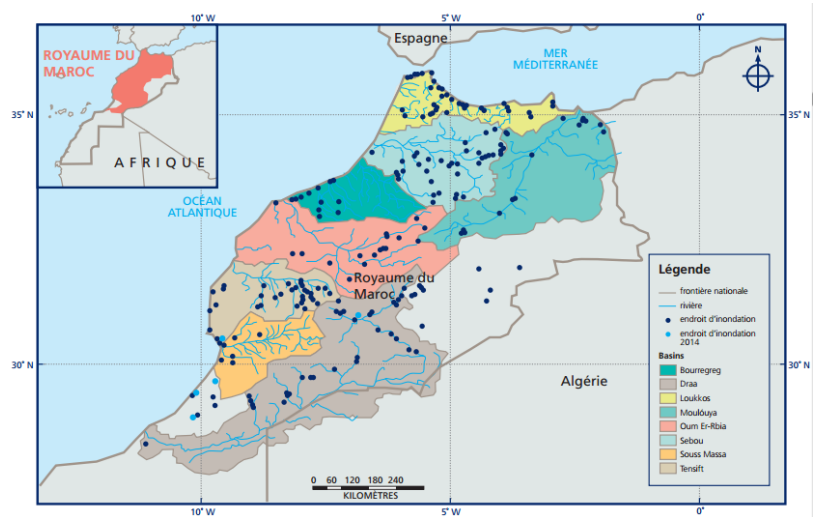

Figure 1. Historical floods events in Morocco [7].

Our study area is located in northern Morocco, the Sebou River Basin. The Gharb plain, located downstream 
of Sebou river, covers an area of about 616,000 hectares with an irrigative potential of 250,000 hectares [10].

The Sebou river basin is one of the most regions that are vulnerable to flooding [19], due to the very irregular regimes of the Sebou and Ouergha rivers. The problem of protecting the Gharb plain against floods affects the irrigation network of the Gharb plain and prevents the optimal management of water resources in the Sebou basin and caused catastrophic material losses [6]. The most devastating floods occurred in the year of 1963, 1973, 1989, 1996, 2009 and 2010. These catastrophic events caused flooding of thousands of hectares on agricultural lands, collapse of houses, thousands of flood victims, disruption of economic activity and damage on infrastructure [6], [11-15].

It should be noted, that in 1963 and 1970, no regulating equipment existed, neither on the Sebou nor on the Ouergha rivers. This gave rise to the launch of several studies on flood protection, notably the Sebou project the study of the problems of flooding in the Gharb plain between "1973 and 1979" [11-12]. All These studies concluded that, to attenuate the effects of flooding is through realizing dams upstream the Sebou and Ouergha rivers, combined with the improvement of the flow in downstream Sebou.

The protection scheme for the Gharb plain was defined by the following hydraulic structures [12], [18]:

- Al Wahda dam, with a total capacity of 3,700 MCM and a flood control section, variable throughout the year, that can reach, during the period of flood occurrence (November to February), more than 1,200 MCM;

- Idriss First dam, with a flood control section, variable over the year, which can reach during the period of flood occurrence (November to February), over 250 MCM;

- Diking downstream of the Sebou river, to achieve a flow rate of $1,500 \mathrm{~m}^{3} / \mathrm{s}$.

Despite these achievements, the Gharb plain experienced significant flooding during the year 2009 and 2010 [13], [19]. These actions have certainly reduced the volumes and duration of the overflows in the Gharb plain, but the extent of the floods observed, shows that the level of protection of the Gharb plain is still low.

The flow records then, show that the maximum flow rate is $4,041 \mathrm{~m}^{3} / \mathrm{s}$ in downstream area of the Ouergha river and $1,445 \mathrm{~m}^{3} / \mathrm{s}$ in the main stream of Sebou river. Moreover, the volume of dam inflow for Al Wahda dam is 7,361 MCM [12].

For the continuation of the irrigation development program in the Sebou basin and the protection of the Gharb plain against flooding, the National Water Plan (20202050) proposes as actions [16-17]:

- Control of the waters of Ouergha river through more storage capacities (additional dams);

- An additional storage capacity for flood control and water regulation;

- A flow rate of the downstream Sebou of around 1450 $\mathrm{m}^{3} / \mathrm{s}$;
- The establishment of a hydro meteorological model, to improve the forecasting actions necessary for floods monitoring.

The main aim of this paper is to evaluate the contribution of increasing the storage capacity in the Ouergha sub-basin on flood protection. This action is carried out by the construction of the Ratba dam with a capacity of one billion cubic meter.

The objectives of the Rabta dam concern, in addition to the protection of the Gharb plain against flooding, the release of an additional water resources and the reduction of the siltation rate observed at $\mathrm{Al}$ Wahda dam reservoir.

\section{Material and methods}

\subsection{Study area}

The surface of Sebou river basin is about $40,000 \mathrm{~km}^{2}$, just $6 \%$ of the total territory but the population of 6.5 million reaches $21 \%$ of the total population of the country. The Sebou river basin, the center of the territory, has largely various features in terms of geology and climatology [16]

Sebou river originates from the Guigou river in the Middle Atlas at 2,030 m altitude. It criss-crosses a length of about $500 \mathrm{~km}$ before reaching its outlet in the Atlantic Ocean in Mehdia (province of Kenitra). This watercourse drains a vast basin with an area of about $40,000 \mathrm{~km}^{2}$. Along its course, Sebou river intercepts several tributaries coming from various regions. The most important tributarie is Ouergha river in the Rif Mountains.

The Sebou basin produces nearly a third of Morocco's surface water, with nearly an average about $4.800 \mathrm{MCM} / \mathrm{y}$. Annual mean precipitation varies between $400 \mathrm{~mm}$ in the valleys of the upper Sebou and Beht river to $1,800 \mathrm{~mm}$ in the high lands of Rif Mountains, consequently the average rainfall is about $700 \mathrm{~mm}$. The flow of the Sebou river is influenced by 10 large dams erected for various reasons such as irrigation (perimeters of Gharb and Beht), drinking water supply, production of electrical energy, protection against floods, control of saline intrusions, water sampling.

The most of the lower Sebou river is dominated by the Gharb plain, a large alluvial plain, bordering the Atlantic coast. The Gharb plain occupies more than $20 \%$ of total agricultural production in Morocco. Therefore, as a national wide project of great importance from the past, the development of irrigation area including irrigation equipment in the Gharb plain is constantly proceeding up to now. Figure 2 shows the Map of Sebou River Basin, which is the project area.

The Ouergha river constitutes the most important subbasin of the Sebou basin, it is characterized by significant flows, although it controls only $15 \%$ of the total area of the Sebou basin $(7,200 \mathrm{~km} 2)$, its participation in contributions exceed 50\% with an average contribution around 2640 MCM against 4.800 MCM. Hence, the Ouergha sub-basin generates significant floods that induce flooding in the Gharb plain [16], [19].

The flow of this river is influenced by severals dams, Sahla (1994, 62 MCM), Bouhouda (1999, 55 MCM), 
Asfalou (2000, $317 \mathrm{MCM})$ and Al Wahda (1997, 3700 MCM).

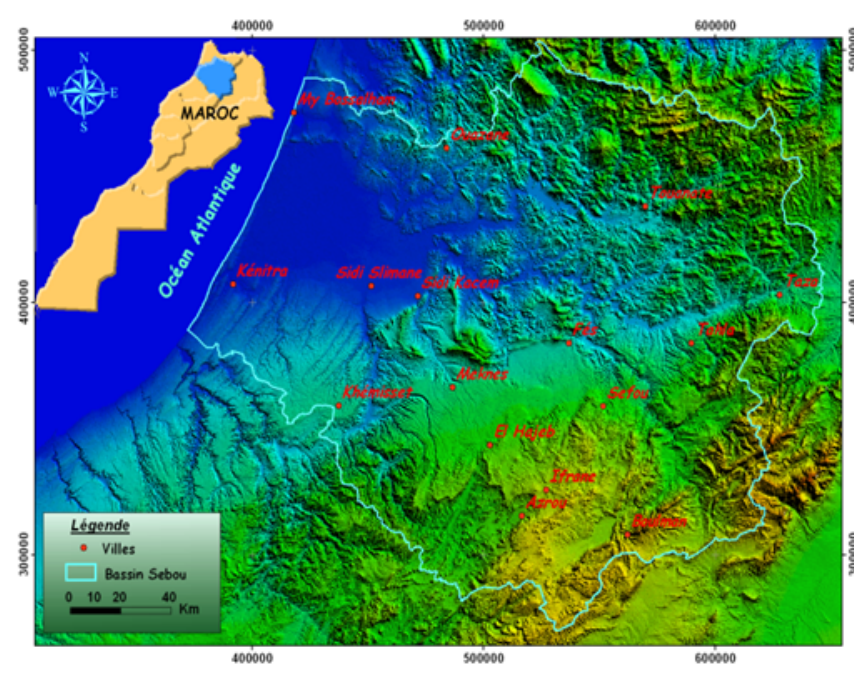

Figure 2. Map of Sebou River Basin.

The Al Wahda dam alone has a storage capacity almost $90 \%$ of Ouergha surface water. The objectives of the dam are the irrigation of the Gharb plain, the public water supply, the production of hydroelectric power and the flood protection of the Gharb plain. The Al Wahda Dam is the centerpiece of the Gharb Plain protection system against flooding.

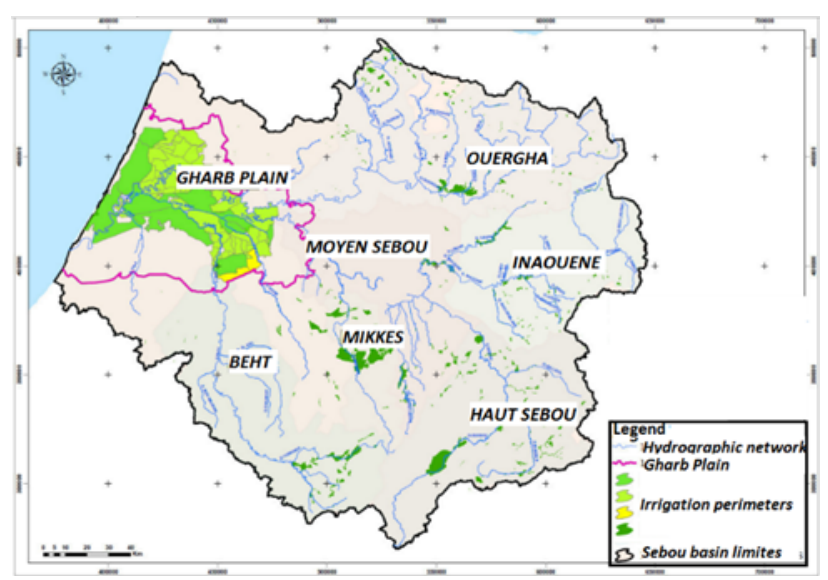

Figure 3. Sebou River Basin and tributaries.

\subsection{Methodology}

In order to meet the objectives of the Ratba dam, a hydraulic simulation study of this new dam was carried out using the River Basin Simulation (RIBASIM) decision support tool [20-22].

The hydraulic simulations extend over the entire Ouergha branch, given the fact that the dam will, in addition to its irrigation supply role, assure the protection of the Gharb plain against flooding.

To do so, the simulations will evaluate the additional irrigation supply volume and we will analyze the outputs of the model to appreciate the impact of the Ratba dam on the protection of the Gharb plain in terms of reducing the volume of water overflow in the Gharb plain.
In order to assess the contribution of the Ratba dam on the protection of the Gharb plain, the used approach includes the:

- Analysis of the current situation of the protection of the Gharb plain against flooding, taking into account the existing dams;

- Evaluation of the situation including the Ratba dam, taking into account the inflow of water from the various strong floods observed at the site of the Ratba dam;

Monthly time step simulations were carried out for different scenarios:

- Scenario SC1: Evaluation of the hydraulic performance of the Ouergha System without Ratba dam;

- Scenario SC2: Evaluation of the hydraulic performance of the Ouergha System with Ratba dam. The Ouergha system is managed in an integrated way, in both situation with or without the Ratba dam, taking into account the resources mobilized and or not mobilized in the basin. The simulations are carried out over the period from [1939-2015]. The figure 4. shows the schematization of the Ouergha hydraulic system used in RIBASIM.

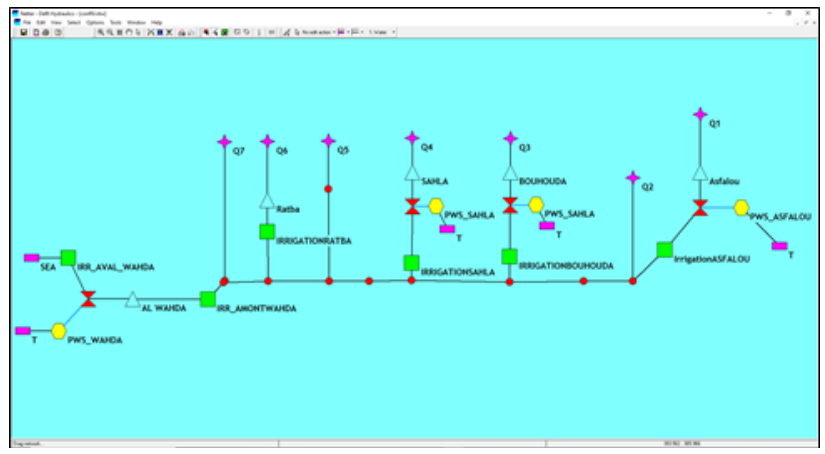

Figure 4. Schematization of the Ouergha River, tributaries, and water users in RIBASIM software.

\subsection{Description of the model}

River Basin Simulations, developed by "Delft Hydraulics" in Holland, is a set of models for planning and management of water resources at watershed level [20-22]. The model compares water supply with current and future demands at different horizons and with different scenarios.

RIBASIM simulates all the behaviors of the hydraulic basins under different hydrological conditions. By changing the inputs of the studied system, different water balances are generated. The evaluation of the hydraulic balances, conclusions and recommendations came out and that should support policy makers.

This model is one of the most used by Moroccan planners, which gives the user a better visibility on the different elements composing a hydraulic model.

The main function used by RIBASIM to assess the variation in stock at Ouergha dams is the hydraulic balance equation:

$$
\Delta V=V E-V S-E N \times S \times 10^{-6}
$$

Where:

$\Delta \mathrm{V}:$ The change in stock in (MCM). 
VE: The volume of natural input evaluated at the dam site in (MCM).

VS: The volume of releases in (MCM).

EN: The net evaporation rate in $(\mathrm{mm})$.

S: The average surface area of the reservoir in $\left(\mathrm{km}^{2}\right)$.

\subsection{Data}

To assess the hydraulic performance of the Ratba dam, the hydraulic simulations required taking into account the following data:

- Inflow of Ouergha tributaries

The simulations are established over the available period from 1939 to 2015. In the Ouergha sub-basin, the surface water resources present an average of $2627 \mathrm{MCM} /$ $\mathrm{y}$. The contribution of each branch is presented in Table 1 .

\begin{tabular}{|l|l|c|}
\hline \multicolumn{2}{|c|}{ Ouergha river tributaries } & Inflow (MCM/y) \\
\hline Assfalou Dam Inflow & Q1 & 87 \\
\hline Bab Ouender Inflow & Q2 & 438 \\
\hline Bouhouda Dam Inflow & Q3 & 301 \\
\hline Sahla Dam Inflow & Q4 & 48 \\
\hline Ratba Dam Inflow & Q5 & 405 \\
\hline Sid EI Mokhfi Inflow & Q6 & 218 \\
\hline Al Wahda Dam Inflow & Q7 & 1130 \\
\hline \multicolumn{2}{|c|}{ OUERGHA INFLOW } & $\mathbf{2 6 2 7}$ \\
\hline
\end{tabular}

Table 1. Ouergha Ouergha River Basin and tributaries Inflow (MCM).

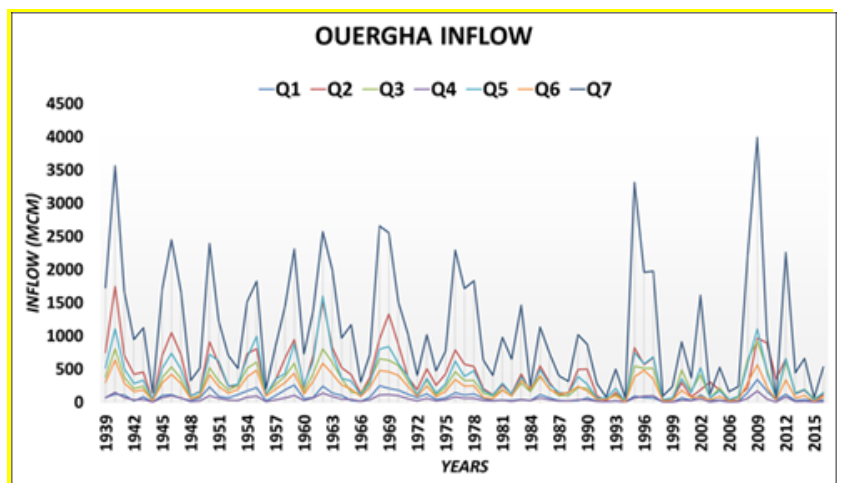

Figure 5. Ouergha River Basin and tributaries Inflow (MCM).

\section{- Dam characteristics}

The characteristics of the dams taken into account in the simulations are presented in Table 2.

\begin{tabular}{|c|c|c|c|}
\hline Dam & $\begin{array}{c}\text { Storage } \\
\text { capacity } \\
\text { (MCM) }\end{array}$ & $\begin{array}{c}\text { Reservoir } \\
\text { level } \\
\text { (mNGM) }\end{array}$ & $\begin{array}{c}\text { Discharge } \\
\text { level } \\
\text { (mNGM) }\end{array}$ \\
\hline Al Wahda & 3373 & 166 & 143 \\
\hline Asfalou & 281.7 & 745 & 714.3 \\
\hline Bouhouda & 44.76 & 382 & 373 \\
\hline Sahla & 67.4 & 372 & 349 \\
\hline
\end{tabular}

\begin{tabular}{|c|c|c|c|}
\hline Ratba & $\mathbf{1 0 1 0}$ & 335 & 272 \\
\hline
\end{tabular}

- The evaporation taken into account in the simulations is recorded at each existing dam. Given the context of the basin, evaporation at the Rabta dam is taken equal to that of the Al Wahda dam.

- The expressed water demands and its modulation are collected from the National Office of Public Water and the Department of Irrigation Services. The total demand simulated is $28 \mathrm{MCM} / \mathrm{y}$ for water public supply and $750 \mathrm{MCM} / \mathrm{y}$ for irrigation supply.

- The flood control curve for Al Wahda dam is:

The volume of the flood control can reach a maximum of 1500 MCM from November to January. The figure. 6 shows the flood control curve considered into the simulation for Al Wahda Dam.

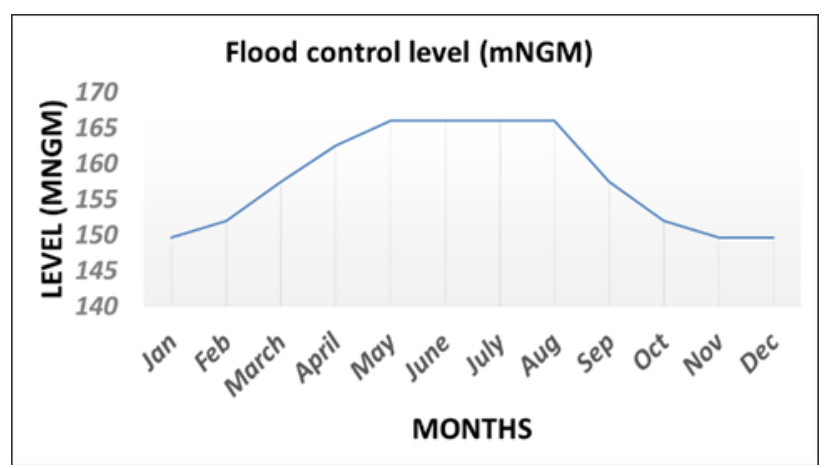

Figure 6. Flood control curve.

\section{- Supply guarantee criteria}

The potential of the resource, expressed in volume of regulated water, depends not only on hydraulic inputs and the physical possibilities of its regulation through hydraulic structures, but also on the guarantee conditions that are required when the resource is called.

The tolerance threshold of a water resource deficit, which cannot be constant, is a determining criterion, which depends fundamentally on the flexibility of the consumer.

The supply guarantee criteria to be respected during the simulation by sector are:

- Public Water Supply:

- Any year in which the annual deficit exceeds $0 \%$ of the total annual need for water public supply (PWS) is considered as a year in deficit;

- Max deficit per year: $0 \%$

- Failure frequency: $0 \%$

- Irrigation:

- Any year in which the annual deficit exceeds $15 \%$ of the total annual need for irrigation water is considered a year in deficit;

- Max deficit per year: $50 \%$

- Failure frequency: 20\% (2/10 years) 


\section{Results and discussion}

For the two scenarios SC1 and SC2, the principle of our simulation consists of an integrated water resources management of the hydraulic system Ouergha.

\subsection{Scenario SC1}

The results of the simulations are summarized in the table 3. below and which show that with an integrated water resources management of the hydraulic system of Ouergha, this makes it possible to regulate a volume of irrigation water supply for Al Wahda dam of around 690 $\mathrm{MCM} / \mathrm{y}$ with a maximum deficit of $50 \%$. The average total volume supplied to the Ouergha basin is estimated at 722 $\mathrm{MCM} / \mathrm{y}$.

According to these results, we notice that the public water demands associated with Asfalou, Sahla, Bouhouda and Al Wahda dams are $100 \%$ satisfied. On the other hand, the irrigation demand from the Sahla dam, the deficit exceeds the maximum deficit admitted; this is due in particular to the strong dry episode that Morocco experienced from the 1980s, including the hydrological year (94-95) remains the largest shortage.

\begin{tabular}{|c|c|c|c|c|c|c|}
\hline & $\begin{array}{c}\text { IRRIGATION } \\
\text { ASFALOV }\end{array}$ & $\begin{array}{l}\text { IRRIGATION } \\
\text { BOtHOLDA }\end{array}$ & $\begin{array}{c}\text { IRRIGATION } \\
\text { SAHLA }\end{array}$ & $\begin{array}{l}\text { RRRIGATION } \\
\text { TPSTREAM } \\
\text { AL, WAHDA }\end{array}$ & $\begin{array}{l}\text { IRRIGATION } \\
\text { DOWNSTREAM } \\
\text { AL WARDA }\end{array}$ & $\begin{array}{c}\text { Total } \\
\text { MCMYY }\end{array}$ \\
\hline $\begin{array}{l}\text { Water } \\
\text { demand } \\
\text { (MCM) }\end{array}$ & 4.4 & 19.7 & 16.5 & 11.6 & 690 & 742.2 \\
\hline $\begin{array}{l}\text { Maximum of } \\
\text { shortage (\%) }\end{array}$ & $52 \%$ & $49 \%$ & $80 \%$ & $52 \%$ & $50 \%$ & - \\
\hline $\begin{array}{l}\begin{array}{l}\text { Average } \\
\text { shortage (\%) }\end{array}\end{array}$ & $3 \%$ & $3 \%$ & $4 \%$ & $3 \%$ & $4 \%$ & - \\
\hline $\begin{array}{l}\text { Average } \\
\text { supply } \\
\text { (MCM) }\end{array}$ & 4.3 & 19.2 & 16 & 11.4 & 671 & 722 \\
\hline $\begin{array}{l}\text { Frequency of } \\
\text { deficiency } \\
\text { (\%) }\end{array}$ & $11 \%$ & $12 \%$ & $12 \%$ & $13 \%$ & $15 \%$ & - \\
\hline
\end{tabular}

Table 3. Simulations results of the first scenario.

To evaluate water overflowed to the Gharb plain, we analyze the amount of water that reached Al Wahda dam especially on the four remarkable floods event 1963, 1970, 1996, 2010. We observe that a large volume will be spilled to the sea during wet years, with a maximum of 6305 $\mathrm{MCM} / \mathrm{y}$ and an average exceeding $1000 \mathrm{MCM} / \mathrm{y}$. Hence, it is mandatory to have an additional storage capacity to benefit from this water loss in times of drought and to minimize flooding downstream of the dam.

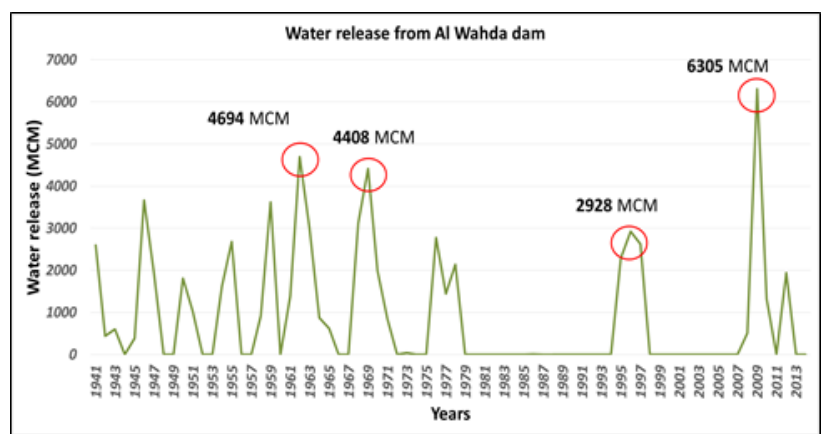

Figure 7. Water release from Al Wahda dam (Scenario 01).

\subsection{Scenario SC2}

After the integration of the Ratba dam with a storage capacity of $1000 \mathrm{MCM}$, for better mobilization of water resources, the current hydraulic system of Ouergha, will regulate maximum water irrigation supply of $870 \mathrm{MCM} / \mathrm{y}$ with an average volume supplied estimated at 853 $\mathrm{MCM} / \mathrm{y}$.

At this storage capacity, the Ratba dam will meet fully its water irrigation needs of $220 \mathrm{MCM} / \mathrm{y}$ (Extension area of irrigation downstream of the dam of around 22,300 Ha according to [17]). Thus, the analysis of its contribution shows that it will regulate an additional volume of 180 $\mathrm{MCM} / \mathrm{y}$ to support supplies downstream of the Al Wahda dam. The summary of the results is given in the following table.

\begin{tabular}{|c|c|c|c|c|c|c|c|}
\hline & $\begin{array}{l}\text { IRRIGATION } \\
\text { ASFALOV }\end{array}$ & $\begin{array}{l}\text { IRRIGATION } \\
\text { BOtHOLDA }\end{array}$ & $\begin{array}{l}\text { IRRIGATION } \\
\text { SAHLA }\end{array}$ & $\begin{array}{l}\text { IRRGARION } \\
\text { TRSIREAM } \\
\text { ALWAHDA }\end{array}$ & $\begin{array}{l}\text { IRRRGATION } \\
\text { RATBA }\end{array}$ & $\begin{array}{l}\text { IRRGATINON } \\
\text { DOWNSIREM } \\
\text { AL WAIDA }\end{array}$ & $\begin{array}{l}\text { Total } \\
\text { MCMYY }\end{array}$ \\
\hline $\begin{array}{l}\text { Water } \\
\text { demand } \\
\text { (MCM) }\end{array}$ & 4.4 & 19.7 & 16.5 & 11.6 & 220 & 650 & 870 \\
\hline $\begin{array}{l}\text { Maximum of } \\
\text { shortage (\%) }\end{array}$ & $49 \%$ & $50 \%$ & $80 \%$ & $50 \%$ & 53 & $52 \%$ & $\cdot$ \\
\hline $\begin{array}{l}\text { Average } \\
\text { shortage (\%) }\end{array}$ & $4 \%$ & $4 \%$ & $5 \%$ & $3 \%$ & $4 \%$ & $3 \%$ & $\cdot$ \\
\hline $\begin{array}{l}\text { Average } \\
\text { supply } \\
\text { (MCM) }\end{array}$ & 4.3 & 19.2 & 16 & 11.5 & 209 & 593 & 853 \\
\hline $\begin{array}{l}\text { Frequency of } \\
\text { deficiency } \\
\text { (\%) }\end{array}$ & $11 \%$ & $11 \%$ & $13 \%$ & $10 \%$ & $12 \%$ & $11 \%$ & $\cdot$ \\
\hline
\end{tabular}

Table 4. Simulations results of the second scenario.

The contribution of Ratba dam on reducing water is appreciated by analyzing the amount of water released by the Al Wahda dam, we notice that for the four events, there is a decrease in the volume that is released downstream $\mathrm{Al}$ Wahda. The maximum recorded in the flood of 2010, goes from $6304 \mathrm{MCM}$ to $4424 \mathrm{MCM}$, i.e. a reduction of nearly $30 \%$ of the volume discharged by the dam. In the same hand, the annual average losses at sea fell from $1000 \mathrm{MCM}$ to $500 \mathrm{MCM}$ with the construction of the Ratba dam.

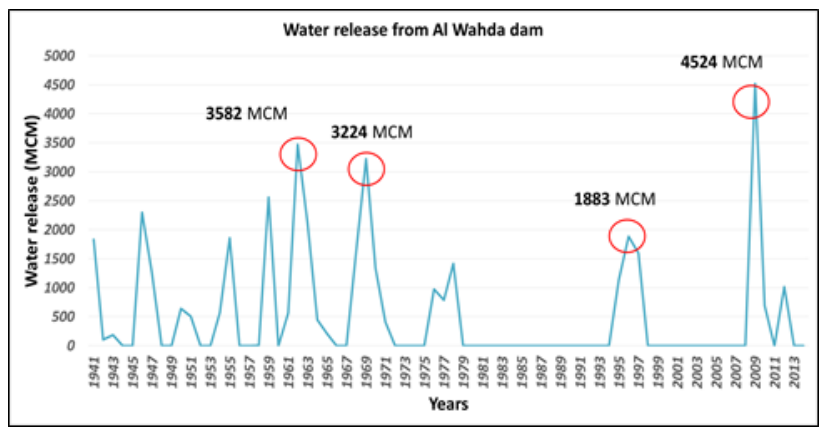

Figure 7. Water release from $\mathrm{Al}$ Wahda dam (Scenario 02).

\section{Conclusion}

The volume of the biggest floods of Ouergha river, recorded at the $\mathrm{Al}$ Wahda dam, which caused catastrophic flooding at the level of the Gharb plain, is around 6 billion cubic meters. In order to, decrease the overflows of the Sebou river, almost all the water inflows, recorded at the Ouergha river, should be stored at upstream dam reservoirs. 
To compensate for the floods of 2010 (6300 MCM), the possibilities for storing the inflows are as follows:

- Al Wahda dam: around 1500 MCM (flood control taken into account in the simulations);

- With a flow rate of $1,450 \mathrm{~m}^{3} / \mathrm{s}$, the volume of water spilled to the sea would be around 2600 MCM (taking into account 20 days as maximum duration of floods);

- Existing and projected dams in Ouergha sub-basin: around $2200 \mathrm{MCM}$.

According the results, the realization of the Ratba dam would have a significant inpact on the overflowed volume in the Gharb plain, during the floods caused by the great floods of the 1963, 1970, 1996 and 2010.

The Ratba dam would reduce by $30 \%$ the volume overflowed in the Gharb plain, depending on the extent of the flood.

Table 5 below gives the contribution of the Ratba dam to attenuate the overflowed volume in the Gharb plain.

\begin{tabular}{|l|c|c|c|c|}
\hline Floods & $\mathbf{1 9 6 3}$ & $\mathbf{1 9 7 0}$ & $\mathbf{1 9 9 6}$ & $\mathbf{2 0 1 0}$ \\
\hline $\begin{array}{l}\text { Overflow } \\
\text { (MCM) }\end{array}$ & 4694 & 4408 & 2928 & $\mathbf{6 3 0 4}$ \\
$\begin{array}{l}\text { Without } \\
\text { Ratba dam }\end{array}$ & 3582 & 3224 & 1883 & $\mathbf{4 5 2 4}$ \\
\hline $\begin{array}{l}\text { Overflow } \\
\text { (MCM) } \\
\begin{array}{l}\text { With Ratba } \\
\text { dam }\end{array}\end{array}$ & & & \\
\hline
\end{tabular}

Table 5. The water released from Al Wahda dam with and without Ratba dam.

Despite this contribution, some actions need to be considered respecting these constraints:

- The capacity at the downstream Sebou river is very low;

- The inflow of the intermediate basin, between $\mathrm{Al}$ Wahda dam and Ratba dam, greatly exceeds the capacity of the flood control volume considered at $\mathrm{Al}$ Wahda dam.

This will lead to significant water releases from the Al Wahda dam, a large part of it will cause the Gharb plain flooding.

The proposed actions for the protection of the Gharb plain against flooding, by the National Water Plan (20202050) [16-17] need to be done simultaneously. In this way, the construction of Ratba dam will not be sufficient to protect against flooding, these actions as follow must be integrated in the same project:

- Control of the waters of Ouergha river through more storage capacities (control all Ouergha tributaries);

- A flow rate of the downstream Sebou of around 1450 $\mathrm{m}^{3} / \mathrm{s}$;

- The establishment of a hydro meteorological model, to improve the forecasting actions necessary for floods monitoring.

This management approach leads to the protection of the Gharb plain and the control of a large part of the Ouergha surface water. The drain of the reservoirs will be carried out during the agricultural season to meet fully the water needs.

It is in this context, that we need to improve water mobilization in the Sebou basin, knowing that it is one of the basins, which has around 30\% of Morocco's surface water. The goal here is to ensure the control of all water supplies to meet fully the water needs of the Sebou basin. And transfer the excess water that is lost at sea, to the basins which suffer from a water resources deficit and whose needs are very important, the Bouregreg and Oum Er Rbia basins, as part of an interconnection project between the Sebou - Bouregreg and Oum Er Rbia basins.

\section{References}

1 Munich RE, NatCat Service; Swiss RE, (2015).

2 James, L. and B. Hall, (1986). Risk information for floodplain management. J. Water Resources Plan. Manage.112:485-499.

3 Gaume, E., Borga, M., Llasat, M. C., Maouche, S., Lang, M. and Diakakis, M., (2016). Mediterranean extreme floods and flash floods. Sub-chapter 1.3.4. p. 133-144.

4 Villevieille, A., (1997). Les risques naturels en Méditerranée. Editeur : Economica, Collection : Les fascicules du plan bleu, 160 pages.

5 Julia Flores, M., Ropero, Rosa F., Rumı, R., (2019). Assessment of flood risk in Mediterranean catchments: an approach based on Bayesian networks. Part of Springer Nature.

6 Dahman Saidi, A., Targa-AIDE and Szönyi, M., (Zurich Insurance Group, 2014). Risk Nexus

7 Inondations au Maroc en 2014 : Quels enseignements tirer de Guelmim et Sidi Ifni.

8 Moroccan Water Department (2002). Morocco flood protection plan, PNI.

9 Benhadi, A. Politique marocaine des barrages (1976) p : 276-294

10 El Ghomari, K. (2015) Bilan de la politique de l'eau au Maroc.

11 ORMVAG, (2011). Etude de faisabilité de l'aménagement hydro-agricole de la TTI du Gharb et de sécurisation de la alimentation en eau de irrigation des secteurs équipés Beht 3 et Beht 4.

12 NEDECO, (1973). Aménagement du bassin de l'oued Sebou équipement hydro-agricole de la plaine $d u$ Gharb.

13 Sebou hydraulic basin Agency. Master plan for integrated water resources management.

14 Sebou hydraulic basin Agency, (2010). Etude de schéma directeur de la protection de la plaine $d u$ Gharb contre les inondations

15 Sebou hydraulic basin Agency, (2013). Etude d'élaboration d'un Schéma Directeur de mise en place d'un système de télémesure au niveau national.

16 Sebou hydraulic basin Agency, (2007). Impact des lacher du barrage Al Wahda sur le bas Sebou.

17 Sebou hydraulic basin Agency, (2020). Updating study of the master plan for integrated water resources management.

18 Moroccan Water Department, (2020). National Water Plan 2020 to 2050 (in progress).

19 Sebou hydraulic basin Agency, (2010). Consignes de gestion des barrages. 
20 Sebou hydraulic basin Agency, (2016). Présentation de la problématique des inondations dans le bassin de Sebou.

21 https://www.deltares.nl/en/software/ribasim/

22 Krogt, V. D. RIBASIM Version 7.00, (2010). Technical reference manual. Delft: WNM Deltares

23 P. van der Zaag, H.G. Savenije. Delft, (2014). Principles of Integrated Water Resources Management. 